\title{
セルオートマトンによる火災時の避難行動のシミュレーション*
}

\author{
小久保 聡*1, 山 本 和 弘 $^{* 2}$, 山下 博 史 ${ }^{* 3}$
}

\section{Simulation of Evacuation Dynamics in Fire by Cellular Automata}

\author{
Satoshi KOKUBO, Kazuhiro YAMAMOTO*4 and Hiroshi YAMASHITA
}

${ }^{* 4}$ Department of Mechanical Science and Engineering, Nagoya University, Furo-cho, Chikusa-ku, Nagoya-shi, Aichi, 464-8603 Japan

\begin{abstract}
Since Cellular Automata (CA) was proposed by von Neumann in the late 1940s, CA have been applied in a variety of scientific researches on complex system, including traffic models and biological fields. It is an idealization of a physical system in which space and time are all discrete. In this study, we have simulated evacuation dynamics in fire by Real-coded Cellular Automata (RCA) proposed as a new approach for pedestrian flow. To consider the flame spread in discrete time and space in calculation, a percolation model is used. We change initial number of people, evacuee velocity, exit width, and flame spread rate. We discuss the total evacuation time and number of fatalities involved in fire.
\end{abstract}

Key Words : Numerical Simulation, Flame, Safety Engineering, Complex System, Cellular Automata, Evacuation

\section{1. 緒言}

避難計画には, 建築物の構造的な安全性と, 火災に 対する安全性を考慮する必要がある，構造的な安全性 に関する基準は法規によって定められているが, 火災 に対する安全性は, 火災という現象そのものが, 様々 な要因によって発生し拡大していくため, 完全な評価 が難しい(1) (4). その中で避難に関する問題は, 人命に 最もかかわる部分であるため, 十分検討する必要があ る. 本来, 実際の火災時のデー夕を蓄積しておくこと が望ましいが，火災発生時のデー夕は限られており， 消火後のデー夕は解釈が困難となる。また，火災の規 模や建物の大きさなどをあらかじめ想定した訓練やデ モ実験を行うことはコスト，時間などの面から現実的 ではない.そこで, 数值解析により火災時の安全性を 検討することは有効であると思われる. 我々はセルオ ートマトンモデルに着目し, 群集行動の解析手法を検 討してきた。

\footnotetext{
* 原稿受付 2008 年 4 月 17 日.

*1 名古屋大学大学院工学研究科 (E 464-8603 名古屋市千種区 不老町).

*2 正員, 名古屋大学大学院工学研究科.

*3 正員, フェロー, 名古屋大学大学院工学研究科.

E-mail : kazuhiro@mech.nagoya-u.ac.jp
}

セルオートマトン法(CA 法) は 1940 年代に von Neumannにより提案され, 現在では流れや拡散現

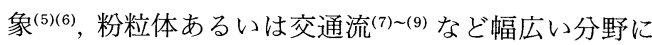
おいて研究されている. 群集行動のセルオートマトン モデルとしては, Floor field model ${ }^{(10) \sim(12)}$ が提案され ている。しかし，人の移動方向が 4 方向に限定されて おり，斜め方向への動きを正確に扱うことができなか った。そこで著者らは流体の分野で応用されている実 数型格子ガス法 (Real-Code Lattice Gas, RLG) ${ }^{(13)(14)}$ に着目し, 人の方向と速度を自由に設定できる実数型 セルオートマトン法(Real-Coded Cellular Automata， RCA)を提案した(15)(16). これまでに, 斜め方向の 移動時間を正確に再現できることを確認しており，ま た，群集の避難行動を解析して出口付近に人がたまる ボトルネック現象や, 密集した人々が通路を移動する ときに見られる自発的レーン形成を模擬することがで きた。

本研究では, Floor field model を考慮した RCA 法 を用いて, 部屋内での火災を想定した避難シミュレー ションを行った，離散モデルにより火炎の燃え拡がり 現象を模擬するため, パーコレーションモデル(17)に より火炎の移動を再現した。人の移動速度，火炎の燃 え拡がり速度, 部屋内の人数などのパラメータを変え 
て解析を行い, 避難できずに火災に巻き込まれてしま う人数と避難時間を調べた. また比較のため, 火災が 発生していない条件, 火災のかわりに障害物を配置す る条件についても同様の計算を行い, 火災時の避難経 路や避難時間について考察した。

\section{2. 計 算 方 法}

2・1 RCA 法 実数型セルオートマトン法 (Real-Coded Cellular Automata)は, 流体の分野で 利用されている実数型格子ガス法を人の移動過程に適 用したものである(15)(16). これにより, 任意の速度を 扱うことができ, 方向についてもセルの向きにとらわ れず自由に設定できる. 時間に関しては従来のものと 同様, 離散的な值をとる. 人の存在位置は格子点上で あり, その移動は現在の位置に人の移動速度べクトル を加えることによって行われる.人の移動過程を詳し く説明する.

$2 \cdot 1 \cdot 1$ 人の移動方法社ま, ある避難している 人の移動速度べクトルを $\boldsymbol{v}_{i}$ とするとき, その $x$ 方向, $y$ 方向成分に分け，それぞれ $v_{x, i}, v_{y, i}$ とする. 格子間 隔を $\Delta$, 時間ステップを $\Delta_{t}$ とし, その時間内に移動 できる距離を格子に対して整数倍の值 $\left[v_{i}\right]$ とそれ以 外の值 $\left\{v_{i}\right\}$ に分けると，

$$
\left\{\begin{array}{l}
v_{x, i} \Delta_{t}=\left[v_{x, i}\right] \Delta+\left\{v_{x, i}\right\} \Delta \\
v_{y, i} \Delta_{t}=\left[v_{y, i}\right] \Delta+\left\{v_{y, i}\right\} \Delta
\end{array}\right.
$$

と表される.したがって, $\left[v_{x, i}\right]\left[v_{y, i}\right]$ と $\left\{v_{x, i}\right\}\left\{v_{y, i}\right\}$ は無次元の值である. セルオートマトン法では人の存 在位置を常に格子点上とするため, まず, $\left[v_{x, i}\right]$ と $\left[v_{y, i}\right]$ の值により上下左右方向に格子点の数だけ移動 させる. 次に残りの小数部分により, 移動を確率過程 として表すことにする(図 1). 図 1 中の格子点 $\mathrm{A}, \mathrm{B}$, $\mathrm{C}, \mathrm{D}$ に移る確率をそれぞれ $p_{A}, p_{B}, p_{C}, p_{D}$ とすると 次のようになる。

$$
\begin{aligned}
& p_{A}=\left\{v_{x, i}\right\} \cdot\left\{v_{y, i}\right\} \quad \ldots \ldots \\
& p_{B}=\left(1-\left\{v_{x, i}\right\}\right) \cdot\left\{v_{y, i}\right\}
\end{aligned}
$$

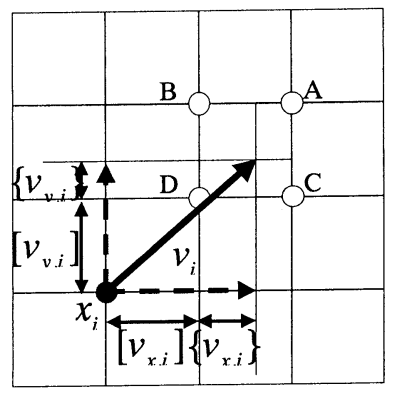

Fig. 1 Position and movement of evacuee

$$
\begin{aligned}
& p_{C}=\left\{v_{x, i}\right\} \cdot\left(1-\left\{v_{y, i}\right\}\right) \cdots \cdots \cdots \\
& p_{D}=\left(1-\left\{v_{x, i}\right\}\right) \cdot\left(1-\left\{v_{y, i}\right\}\right) \cdots
\end{aligned}
$$

すなわち, 人の位置をこの確率により周囲 4 つの格子 点に移動させる.もちろん, 4 つの格子点の中でもべ クトルの先端位置から 1 番近い点を選ぶ確率が高くな るが, 他の点を選んで移動することも確率的に起こ る.このように従来の CA モデルと同様に人の位置は 格子点とするが, 任意の速度と方向の移動が扱えるこ とになる。

$2 \cdot 1 \cdot 2$ 人の向きの変更次に人の向きを変更す る手順について説明する. $2 \cdot 1 \cdot 1$ 項で説明した人の配 置後に, すべての人に対して目的地の方向(出入り口 など）に向きを変えるという作業を行う.このとき， 人の移動方向は, 出口までの最短経路を記述するフロ アフィールドの值を参照して決定する. フロアフィー ルドとは, 出口までの正確な距離が記述されている場 のことである(10) (12). 図 2 に, 部屋内に障害物がある 場合とない場合のフロアフィールドを示した. 黒色か ら白色に変わるに従って出口からの距離が遠いこと (フロアフィールドの值が高いこと)を示している.人 はこの等高線に垂直な方向に進む. また, 避難経路の 途中に火炎がある場合は, 火炎からある距離 $L($ 今回 は $1.6 \mathrm{~m}$ 一定) 離れるように迂回して避難することに した.

また，既に移動する地点に人がいる場合や障害物に 衝突する場合など, 移動の過程で前に進めない場合に は, 向きを変えることにする. 今回はその過程を簡略 化し, 元の方向からの変換量を $+45^{\circ}$, または $-45^{\circ}$ と した [図 3(a)]. 図 3(a)において, 実線はもとの移 動方向, 点線は変換後の移動方向である.この $45^{\circ}$ の 大きさは, 現実に人が動いているときにとっさに変え ることのできる角度に相当する. その向き $(+\mathrm{or}-)$ は, 人の数がなるべく少ない方向を選択するが, 移動 予定の点がすでに延焼している領域となっている場合 は上記のルールは適用せず, 火炎から離れる方向に向 きを $45^{\circ}$ 変えることにした [図 3(b)].
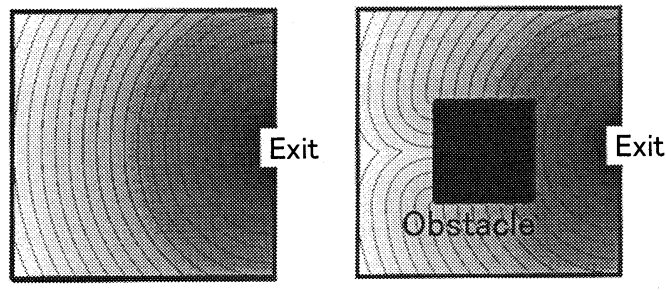

(a) Room with no obstacles (b) Room with an obstacle

Fig. 2 Floor field in room 


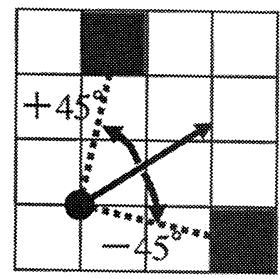

(a) Change of direction

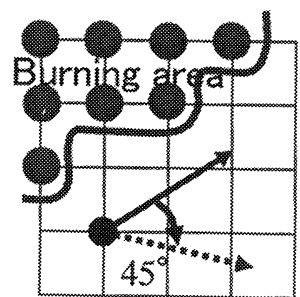

(b) Change of direction in case of fire
Fig. 3 Update rule of direction

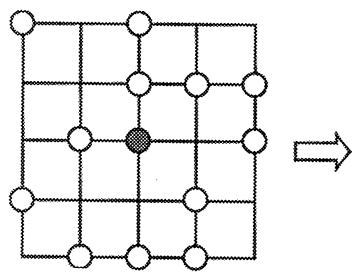

(a) Before flame spread

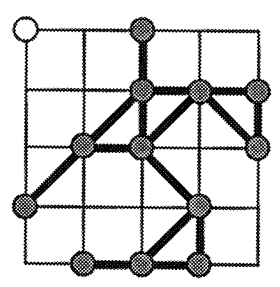

(b) After flame spread
Fig. 4 Percolation model

$2 \cdot 2$ 火炎の燃え拡がり 次に, パーコレーショ ンモデルによる火炎の燃え拡がりの計算方法について 説明する.パーコレーションは，浸透現象を説明する ために提案されたモデルであり, 森林火災や伝染病の 伝播などをこのモデルにより再現することができるこ とが知られている(17). 最近の研究では, 空間中に液滴 などの燃料がランダムに分散している場合を想定し， それらのつながりを考えることで噴霧燃焼を模擬した 研究例も報告されている(18)(19).

図 4 に本解析において用いた火炎の燃え拡がりのモ デルを示す．燃焼可能な点を丸の点で示し，白丸で示 した燃焼前の点が燃焼して黒丸の点に変化する．計算 では，初期に部屋の中央に着火源を置き [図 4(a)], 燃焼した点が隣接した末燃の点に移ることで火炎の伝 播を模擬した. 従来のパーコレーションの計算モデル では, 火炎の移動を 2 次元平面における上下左右の方 向しか考慮していなかったが，本モデルでは同心円状 の火炎の燃え拡がりを模擬するため, 斜め方向も考慮 することにした [図 4(b)]. また，中心部分に設けた 着火源から，火炎を同心円状に伝播させたとき，上下 左右方向へ燃え拡がる確率を $P_{1}$, 斜め方向へ燃え拡が る確率を $P_{2}$ とした。

$2 \cdot 3$ 計算領域次に計算領域について説明する. 本研究では, 火災の発生していない部屋として部屋 $\mathrm{A}$, 火炎のかわりに障害物を配置した部屋 $\mathrm{B}$, 火災の

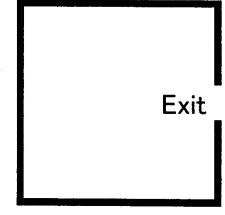

(a) Room A (b) Room B

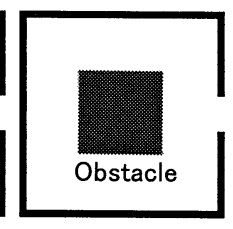

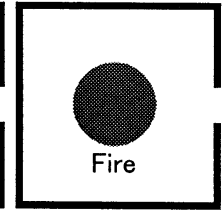

(c) Room C
Fig. 5 Evacuation in three Rooms $\mathrm{A}$ to $\mathrm{C}$

発生している部屋 C の解析を行い, 様々なパラメータ を変えることで, 避難行動にどのような違いが現れる かを調べた(図 5). 部屋の大きさはすべて $16 \mathrm{~m} \times 16$ $\mathrm{m}$ で正方形の形状の部屋とし, 出口を部屋の右側の壁 の中央に配置している. 出口の大きさは $W$ とした. 部屋 $\mathrm{B}$ には $6.4 \mathrm{~m} \times 6.4 \mathrm{~m}$ ままたは $8.8 \mathrm{~m} \times 8.8 \mathrm{~m}$ の 正方形の障害物を中心に配置した，火炎の発生する部 屋 Cでは, 部屋内のすべての領域を燃焼可能な点とし た.

一方, 計算初期における部屋内の人の配置は乱数に より与えた.ここで, 初期人数を $N$, 火炎の燃え拡が り速度を $v_{f}$, 避難者の移動速度を $v_{i}$ とした. 今回の 計算で用いる $v_{i}$ としては, ジョギング程度の速度 $v_{i}$ $=2.2 \mathrm{~m} / \mathrm{s}$, 全速力の速度 $v_{i}=5.0 \mathrm{~m} / \mathrm{s}$, その間の速度 $v_{i}=3.0 \mathrm{~m} / \mathrm{s}$ とした. 格子間隔 $\Delta$ は人の肩幅の平均值 である $0.4 \mathrm{~m}, 1$ タイムステップ $\Delta_{t}$ を $0.5 \mathrm{~s}$ とした。 また，避難できずに火災に巻き込まれてしまった人の 人数を $N_{D}$, 避難開始時間から部屋内にいるすべての 人が避難を完了する時間を $T_{E}$ とし, 様々な計算条件 に対して $N_{D}$ と $T_{E}$ を求めた。

\section{3. 計算結果及び考 察}

$3 \cdot 1$ 火炎の燃え拡がりの様子 まず, 避難の解 析を行う前に火炎が同心円状に燃え拡がる条件につい

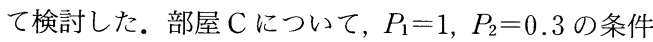
での火炎の燃え拡がりの様子を図 6 に示す.ここで, 着火後の火炎の位置について検討するため, 図 6(a) に示すように, 上下左右を $1,2,3,4$ 方向, 斜めを 5 , $6,7,8$ 方向とし, 各方向の火炎位置 $X_{f}$ の時間変化を 調べた.その結果を図 7 に示す。 1 方向と $5,6,7,8$ 方向の火炎の位置はほぼ一致していることが確認でき る.また, 火炎位置の時間変化もほぼ同じであったこ とから, $P_{2}=0.3$ とすることで, 火炎が同心円状にほ ぼ一定の速度で伝播する現象を再現できた。

また, $P_{1}=C$ と $P_{2}=0.3 C$ として, 火炎の燃え拡が り速度 $v_{f}$ を変化させた. 図 8 にと $v_{f}$ の関係を示 した.この結果，Cの值により確率 $P_{1}$ と $P_{2}$ の值を同 時に変化させ, $v_{f}$ の值を $0.8 \mathrm{~m} / \mathrm{s}$ 以下の範囲で任意 


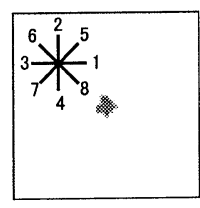

(a) $t=1 \mathrm{~s}$

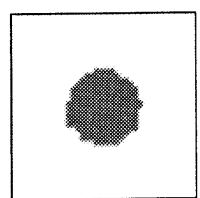

(b) $t=4 \mathrm{~s}$

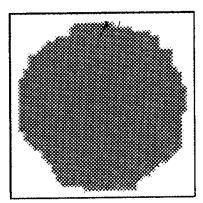

(c) $t=9 \mathrm{~s}$
Fig. 6 Fire spread

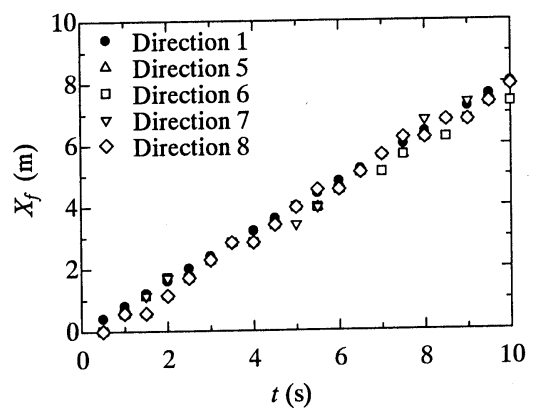

Fig. 7 Flame position along 1, 5, 6, 7, and 8 directions

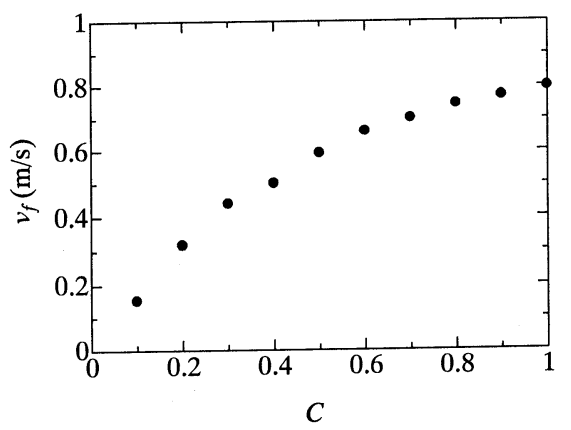

Fig. 8 Flame spread rate

に変えることができた，そこで本解析では，この $C$ の值により火炎の燃え拡がり速度 $v_{f}$ を変化させた.

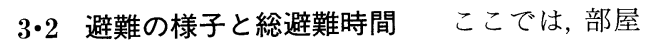
$\mathrm{A} \sim \mathrm{C}$ での避難経路と総避難時間 $T_{E}$ の違いについて 検討した. 図 9〜11に, 各部屋 $\mathrm{A} \sim \mathrm{C}$ について, $N=$ $100, v_{i}=2.2 \mathrm{~m} / \mathrm{s}, W=1.2 \mathrm{~m}, v_{f}=0.8 \mathrm{~m} / \mathrm{s}$ の条件で 計算を行い, $0.5,5,9$ 秒後の人の位置を図示した.た だし，部屋 $\mathrm{B}$ の障害物の大きさは $8.8 \mathrm{~m} \times 8.8 \mathrm{~m}$ であ る.

これによると, 火炎のない部屋 A では人は最短経 路を, ほぼ直線的に出口へ向かっている. また, $t=5$ $\mathrm{s}$ において出口付近にボトルネックの現象が観察され た.一方, 障害物のある部屋 B では, 迁回しながら避 難する様子が観察された。ただし部屋 A の結果とは 異なり, はじめはランダムに配置した人々が一斉に出

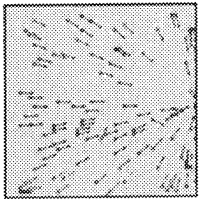

(a) $t=0.5 \mathrm{~s}$

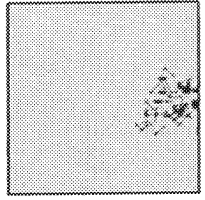

(b) $t=5 \mathrm{~s}$

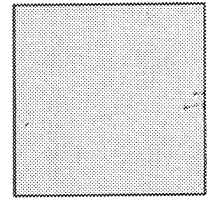

(c) $t=9 \mathrm{~s}$
Fig. 9 Evacuation simulation in Room A

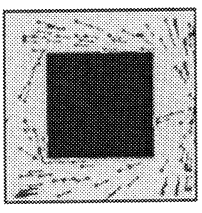

(a) $t=0.5 \mathrm{~s}$

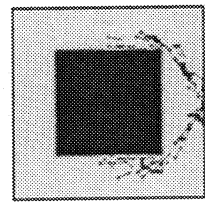

(b) $t=5 \mathrm{~s}$

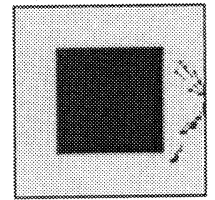

(c) $t=9 \mathrm{~s}$
Fig. 10 Evacuation simulation in Room B

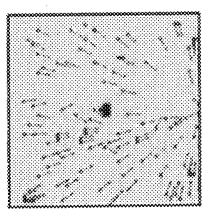

(a) $t=0.5 \mathrm{~s}$

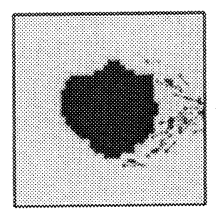

(b) $t=5 \mathrm{~s}$

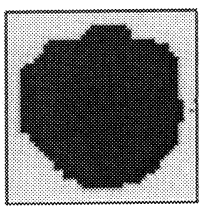

(c) $t=9 \mathrm{~s}$
Fig. 11 Evacuation simulation in Room C

口に向かうが, 時間がたつにつれて中央に配置した障 害物の角に人が群がって渋滞している様子が見られ た.おそらく避難者はこの場合, 最短の経路をとるた め障害物の角をめざして移動するので, 出口付近で見 られるボトルネックの現象が障害物の角でも観察され ることになったと思われる。一方, 火災の発生してい る部屋 Cの場合, 時間がたつにつれて延焼している領 域が拡大するため, 部屋 $\mathrm{A}$ と B に比べ, ボトルネッ クの発生時刻や, 避難経路に大きな違いがみられた。

また, 図 12 に各部屋について初期配置人数 $N$ を変 化させて得られた総避難時間 $T_{E}$ の結果を示す。ここ では $v_{f}=0.5 \mathrm{~m} / \mathrm{s}$, 障害物の大きさ $8.8 \mathrm{~m} \times 8.8 \mathrm{~m}$ と して計算を行い, 図 12 中の各プロットは, 人の初期配 置を変えた 5 回のシミュレーションの平均值をとった 結果である. 部屋 Cでは初期配置人数が 100 人より 大きくなると火災に巻き込まれてしまう人が増え, 総 避難時間が決定できなくなるため, 100 人以下の結果 のみを示した。

これによると, どの場合でも部屋内の人数が多くな ると, 避難時間がほぼ比例して大きくなることがわか った。また, 部屋 $\mathrm{A}$ と部屋 $\mathrm{B}$ を比べると, 部屋 $\mathrm{B}$ の 


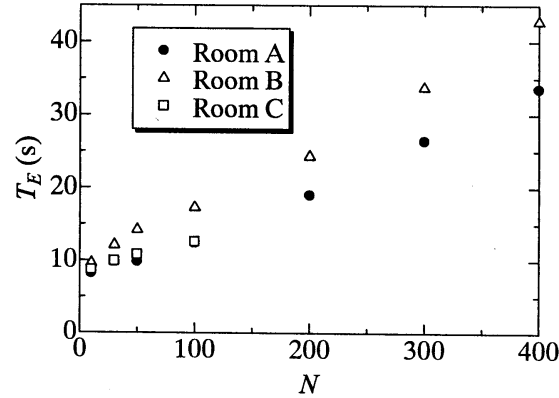

Fig. 12 Variation of $T_{E}$ at different value of $N$

方が避難時間は 3 割程度長くなっている。これは, 障 害物を迂回するため, 移動距離が長くなり，また，障 害物の角付近で起きる渋滞により出口に到着する時間 が遅れるためである，また，障害物をより大きくする と, 総避難時間が長くなることがわかった。

ここで, 避難時間について考察を行った。図 12 に よれば初期配置人数が少ない時 $(10$ 人)のときは, 総避

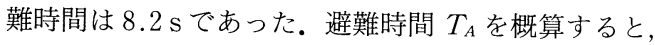
部屋の一番遠い場所にいる人は, 出口まで

$\sqrt{16^{2}+8^{2}}=17.9[\mathrm{~m}]$

の距離を移動する必要がある。この距離を人の避難速 度 $2.2 \mathrm{~m} / \mathrm{s}$ で割ると, 避難時間は

$$
T_{A}=\frac{17.9}{2.2}=8.1[\mathrm{~s}]
$$

となり, 初期配置人数が少なくボトルネックがみられ ない場合は, 避難時間が単純に移動距離を移動速度で 割った值となるといえる。ただし，図 9(b)でもわか るようにボトルネックが発生する初期配置人数 100 人 のときは総避難時間は $12.5 \mathrm{~s}$ となっているので, ボ卜 ルネックが発生すると総避難時間が長くなることがわ かった。

文献(1)によれば, 幅 $W[\mathrm{~m}]$ の出口から人数 $P$ [人]の人々が避難するときに要する時間 $T_{B}[\mathrm{~s}]$ は,

$$
T_{B}=\frac{P}{a W}
$$

となる。ここで $a[$ 人/(m・s)] は群集流出係数と呼ば れ，避難時には 1.5 の值が推奨されている。この式を 用い, 総避難時間を見積もることにした。まず，部屋 内で一番遠くにいる人が避難する時刻が, 総避難時間 になるとする. 出口に到着する時刻 $T_{A}$ は式 ( 7 ) より $8.1 \mathrm{~s}$ である。計算開始直後からボトルネックの現象 が起きているとすれば, 時刻 $T_{A}$ の時点で出口から部 屋をすでに出た人数 $P_{a}$ は,

$$
P_{a}=a \times T_{A} \times W
$$

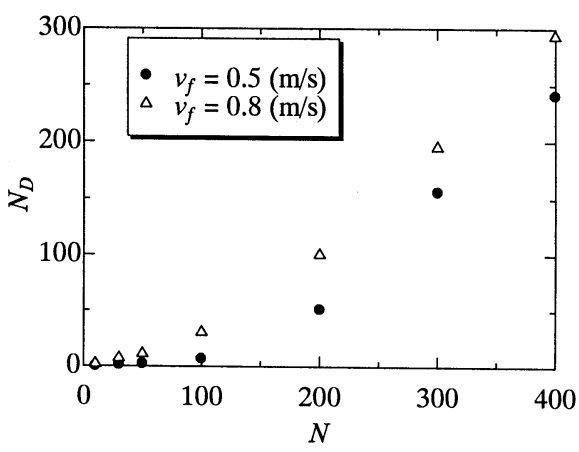

Fig. 13 Variation of $N_{D}$ at different value of $N$

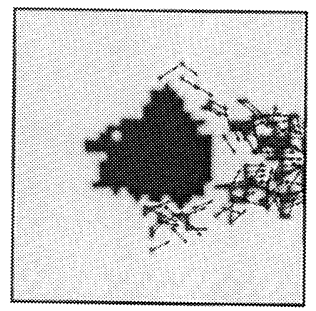

(a) $v_{f}=0.5 \mathrm{~m} / \mathrm{s}$

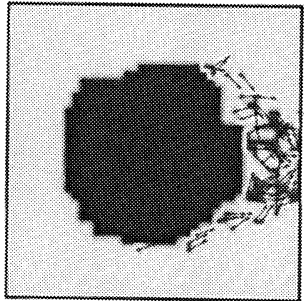

(b) $v_{f}=0.8 \mathrm{~m} / \mathrm{s}$
Fig. 14 Difference of evacuee's position at $6 \mathrm{~s}$

となる.出口幅は $1.2 \mathrm{~m}$ であるので,

$P_{a}=1.5 \times 8.1 \times 1.2 \cong 15$ [人]

となる. 初期配置人数を 100 人とすると, 一番遠くに いる人が出口に到着した時点で残りの 85 人がボトル ネックの人数となる.よって, 式（8)より,

$$
T_{B}=\frac{P}{a W}=\frac{85}{1.5 \times 1.2} \cong 70.8[\mathrm{~s}]
$$

となり, 総避難時間 $T_{E}$ は,

$$
T_{E}=T_{A}+T_{B}=8.1+70.8 \cong 79[\mathrm{~s}]
$$

となった。これは, 図 12 の $12.5 \mathrm{~s}$ と大幅に異なる結 果となった。その原因として, ボトルネックが発生す る時刻を計算開始直後と仮定したこと, また, 理論式 で用いた群集流出係数 $a$ も改札口, 映画館や百貨店出 口で異なる值が報告されるなど, 正確な值が不明であ ることが考えられる。

$3 \cdot 3$ 火炎の燃え拡がり速度の影響 次に, 火炎 の燃え拡がり速度を変えて火災に巻き込まれる人数 $N_{D}$ を調べた. 図 13 亿部屋 C について, 避難者の速度 $v_{i}=2.2 \mathrm{~m} / \mathrm{s}, W=1.2 \mathrm{~m}$ の条件で, 初期配置人数 $N$ を変化させて得られた 5 回のシミュレーションの平均 值を示す. 火炎の燃元拡がり速度 $v_{f}=0.5,0.8 \mathrm{~m} / \mathrm{s}$ について比較した. 図 14 は $N=200$ のときの 6 秒後 の人と火炎の位置の違いを示したものである.

図 13 より, 初期配置人数 $N$ が小さいときは火災に 


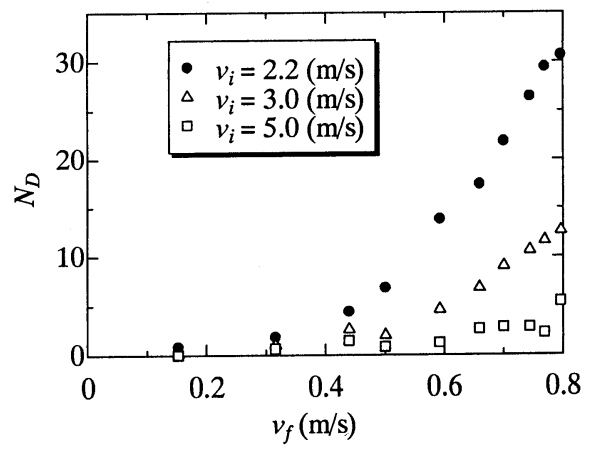

Fig. 15 Variation of $N_{D}$ at different value of $v_{f}$

巻き込まれる人数 $N_{D}$ も小さいが, 部屋内の人数が多 くなると, $N_{D}$ が急激に増加することがわかった.こ れは, 人数が少ないとボトルネックが発生せずスムー ズに出口を通過し避難できるが, 人数が増えることに より出口付近でのボトルネックが起きやすくなり, 避 難できない人が増えてくるためである. また，火炎の 燃え拡がり速度を大きくすると，火災に巻き込まれる 人数が増えることがわかる. 図 14 によれば, 同時刻 でも火炎の大きさは大きく異なる，火炎が大きい場合 は, 出口付近だけでなく, 避難途中で火災に巻き込ま れる人が増えることがわかった。

また, $v_{i}=2.2,3.0,5.0 \mathrm{~m} / \mathrm{s}, N=100, W=1.2 \mathrm{~m}$ の条件で, 火炎の燃え拡がり速度 $v_{f}$ を変化させて $N_{D}$ を求めた。 5 回のシミュレーションの平均值を図 15 に示す。これによると, 火炎の燃え拡がり速度が速い ほど，火災に巻き込まれる人数が大きくなることがわ かった。これは, 火炎の近くを移動している人だけで なく, 出口により早く火炎が到達し, 避難できず出口 付近に集まっている人を巻き込んでしまうためであ る.ただし, 避難者の移動速度 $v_{i}$ を大きすること で, $N_{D}$ が小さくなった. 特に, 移動速度が $5.0 \mathrm{~m} / \mathrm{s}$ の条件では, 火炎の燃え拡がり速度 $v_{f}$ が速くなって も $N_{D}$ は小さい值のままであった。したがって, 火炎 の燃え拡がり速度 $v_{f}$ に対して避難者の移動速度 $v_{i}$ が 相対的に大きいほど，火災に巻き込まれる人数が少な くなるといえる.

$3 \cdot 4$ 出口幅の影響最後に, 部屋の出口幅の影 響について調べた。図 16 は, 火災が発生していない 条件の部屋 A について, $v_{i}=2.2 \mathrm{~m} / \mathrm{s}, N=100$ の条件 での 8 秒後の人の位置を示したものである. 出口幅 $W$ は $0.4 \mathrm{~m}$ と $2.0 \mathrm{~m}$ のものを示した.これによると, $W=0.4 \mathrm{~m}$ のときに出口付近で観察されたボトルネ ックの現象が, $W=2.0 \mathrm{~m}$ では見られていない.これ

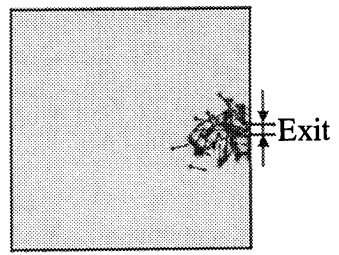

(a) $W=0.4 \mathrm{~m}$

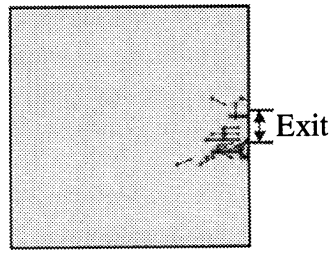

(b) $W=2.0 \mathrm{~m}$
Fig. 16 Evacuee's position at $8 \mathrm{~s}$

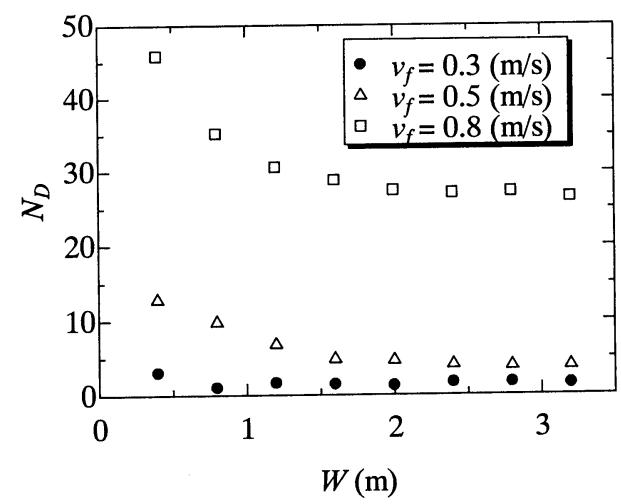

Fig. 17 Variation of $N_{D}$ at different value of $W$

は, 出口幅が大きくなることで, 人がスムーズに部屋 から出ることができるようになったためである.

次に, 火災が発生している部屋 Cについての結果を 示す. 図 17 は, $v_{i}=2.2 \mathrm{~m} / \mathrm{s}, N=100, v_{f}=0.3,0.5$, $0.8 \mathrm{~m} / \mathrm{s}$ の条件で, 出口幅 $W$ を変化させて得られた $N_{D}$ の平均值を示す. 出口幅 $W$ を大きくしていくと, はじめ火災に巻き込まれる人数 $N_{D}$ は小さくなった が, 図 16 で示されるように, ボトルネックが観察され なくなる $1.6 \mathrm{~m}$ 以上になると一定の值をとった. 出 口幅が小さい時には，単位時間に出口を通過できる人 数が少ないために, ボトルネックが発生し, 出口付近 で多くの人が火災に巻き込まれるが, 出口幅が大きい とボトルネックが発生しにくいため, $N_{D}$ が小さくな ったものと思われる。 また, 火炎の燃え拡がり速度 $v_{f}$ が小さいほど, $N_{D}$ は小さくなった. 特に $v_{f}=0.3$ $\mathrm{m} / \mathrm{s}$ の条件では, 避難者の移動速度が火炎より十分速 いため, 出口の大きさにかかわらず, $N_{D}$ は非常に小 さい値となった.

\section{4. 結言}

本研究では $16 \mathrm{~m} \times 16 \mathrm{~m}$ の部屋内の火災を想定し, 避難行動を実数型セルオートマトン法 $(\mathrm{RCA})$ により 数值的に模擬した. 火炎の燃え拡がりはパーコレーシ 
ヨンモデルにより再現した. 比較のため, 火災がない 場合と火災のかわりに部屋内に障害物を配置する場合 についても同様の計算を行い, 火災時の避難経路や避 難時間について検討した. その結果, 以下のことが明 らかとなった。

（1） パーコレーションモデルで火炎の燃え拡がり 現象を模擬したところ, 上下左右方向を $P_{1}=1$, 斜め 方向を $P_{2}=0.3$ とすると, 火炎がほほ同心円状に拡が る.また, $P_{1}=C, P_{2}=0.3 C$ とすることで $0.8 \mathrm{~m} / \mathrm{s}$ までの任意の燃え拡がり速度を設定できる.

（2）部屋内に障害物や火炎が存在すると人の避難 経路が変わるため総避難時間が 3 割程度増える.ま た, 出口におけるボトルネックの発生に差が見られ た.

（3）火炎の燃え拡がり速度が遅いほど, また避難 する人の移動速度が速いほど, 逃げ遅れて火災に巻き 込まれる人数は少なくなる.

（4）出口幅が大きくなると，火災に巻き込まれる 人数は減少するが, 出口でボトルネックが見られなく なる出口幅 $1.6 \mathrm{~m}$ 以上で, ほぼ一定の值になった。 本研究の一部は豊田理化学研究所の助成を受けた. ここに記して謝意を表す。

\section{文献}

(1) Tanaka, T., Textbook on Architectural Fire Safety Engineering, (1993), Japan Architectural Center.

(2) Hirano, T., Combustion Science for Safety, Proceedings of the Combustion Institute, Vol.29 (2002), pp. 167-180.

(3) Yamamoto, K., Mori, K. and Onuma, Y., Effects of Ambient on Flame Spread over Solid Fuel, Trans., Japan Society for Mechanical Engineers, Vol. 68, No. 672 (2002), pp. 2437-2443.

(4) Yamamoto, K., A Study for Model of Flame Spread over Solid Fuel, Trans., Japan Society for Mechanical Engineers, Vol. 69, No. 680 (2003), pp. 954-961.

(5) Matsukuma, Y., Takahashi, R., Abe, Y. and Adachi, H., Lattice Gas Automata Simulations of Flows through Complex Geometry, Japan Society for Mechanical Engineers, Vol.64, No. 622 (1998), pp. 1617-1622.
(6) Toba, K., Morishita, S. and Itagaki, S., Simulation of Diffusion Phenomena by Cellular Automata, Symposium on Environmental Engineering, Vol. 2001 (2001), pp. 53-56.

( 7 ) Yamamoto, N. and Morishita, S., Simulation of Traffic Flow by Cellular Automata and its Control, Japan Society for Mechanical Engineers, Vol.65, No. 637 (1999), pp. 3553-3558.

(8) Tamaki, T., Yasue, S. and Kita, E., Traffic Simulation Using Cellular Automata, Design \& Systems Confer. ence, Vol. 2002-12 (2002), pp. 440-441.

(9) Morishita, S. and Shiraishi, T., Evolution of Billboards Based on Pedestrian Flow in the Concourse of the Station, Lecture Notes in Computer Science, LNCS 4173 (2006), pp. 716-719.

(10) Burstedde, C., Klauck, K., Schadschneider, A. and Zittartz, J., Simulation of Pedestrian Dynamics Using a Two-Demensional Cellular Automaton, Physica A, Vol. 295 (2001), pp. 507-525.

(11) Nishinari, K., Kirchner, A., Namazi, A. and Schadschneider, A., Extended Floor CA Model for Evacuation Dynamics, IEICE Transactions on Information and Systems, E 87-D (2004), pp. 726-732.

(12) Yanagisawa, D. and Nishinari, K., Reports of RIAM Symposium (in Japanese), No. 17 ME-S 2, Article No. 28 (2006).

(13) Hashimoto, Y., Chen, Y. and Ohashi, H., Immiscible Real-Coded Lattice Gas, Computer Physics Communications, Vol. 129 (2000), pp. 56-62.

(14) Malevanets, A. and Kapral, R., Europhysics Letters, Vol. 44 (1998), pp. 552-558.

(15) Yamamoto, K., Kokubo, S. and Nishinari, K., New Approach for Pedestrian Dynamics by Real-Coded Cellular Automata (RCA), Lecture Notes in Computer Science, LNCS 4173 (2006), pp. 728-731.

(16) Yamamoto, K., Kokubo, S. and Nishinari, K., Simulation for Pedestrian Dynamics by Real-Coded Cellular Automata (RCA), Physica A, Vol. 379 (2007), pp. 654660 .

(17) Konno, N., Complex system, (1998), pp. 155-196, Natsume Publising Company.

(18) Takamori, S. and Umemura, A., Application of Percolation Theory to Spray Combustion, Journal of the Combustion Society of Japan (in Japanese), Vol. 45, No. 132 (2003), pp. 95-102.

(19) Oyagi, H., Yagi, K., Shigeno, H., Mikami, M. and Kojima, N., Flame-Spread Characteristics of Randomly Fuel-Droplet Arrays in Microgravity, Journal of the Combustion Society of Japan (in Japanese), Vol. 49, No. 147 (2007), pp. 62-69. 